\title{
MEMAKNAI BENTUK RUPA LAMBANG KERATON MANGKUNEGARAN
}

\author{
Herliyana Rosalinda ${ }^{1}$, Umi Kholisya ${ }^{2}$
}

Program Studi Desain Komunikasi Visual

Fakultas Bahasa dan Seni, Universitas Indraprasta PGRI, Jakarta. herliyanarosalinda1990@gmail.com ${ }^{1}$,umi_history@yahoo.com ${ }^{2}$

\begin{abstract}
Abstrak
Penelitian ini bertujuan untuk mendeskripsikan Makna Simbolis Lambang Keraton Mangkunegaran Surakarta. Pmbahasannya digolongkan sebagai penelitian deskriptif kualitatif menggunakan metode historis, untuk menafsirkan makna simbol yang ada pada lambang keraton Mangunegaran digunakan pendekatan hermeunitika. Objeknya Keraton Mangkunegaran Surakarta sedangkan subjek penelitian ini adalah Makna Simbolis Lambang Keraton. Penelitian juga difokuskan pada hal-hal yang berkaitan dengan pemerintahan kerajaan Mangkunegaran Surakarta, selain itu pemaknaan lambang sebagai identitas legitimasi suatu pemerintahan dalam kerangka budaya juga menjadi kajian yang penting, terutama dari bentuk visual, rupa, maksud atau makna simbolik yang ada pada lambang kerajaan Mangkunegaran Surakarta. Hasil penelitian menunjukkan: pada setiap periodesasi pemerintahan Mangkunegara, lambang Mangkunegaran memiliki bentuk rupa dan makna simbol yang berbeda-beda. Hal ini disesuaikan dengan karakteristik pemikiran, pemerintahan, maupun filosofis dari dalam diri raja Mangkunegaran yang sedang memerintah. Umumnya unsur gambar yang ada pada lambang Mangkunegaran berisi gambar mahkota, padi dan kapas, surya, dan logotype MN. Sedangkan untuk perbedaannya ddilihat dari perbedaan tampilan bentuk ataupun jumlah masing-masing jenis gambar tersebut.
\end{abstract}

Kata Kunci : Bentuk rupa, Simbol, Lambang, Mangkunegaran

\section{INTERPRET SHAPE OF EMBLEM ON MANGKUNEGARAN PALACE}

\begin{abstract}
This study aimed to describe the Meaning of Mangkunegaran Surakarta Symbol. The explanation of this study classed as a qualitative descriptive using historical methods, and then to interpret the meaning of the symbol on the emblem used Mangunegaran palace hermeunitika approach. The object is Kraton Mangkunegaran while the subject of this study was the Meaning of Symbol palace. These study focused to the royal government Mangkunegaran, in addition to the meaning of the emblem as the identity of the legitimacy of a government within the framework of culture is also important, especially in the visual form, appearance, purpose or symbolic meanings that exist in the royal Mangkunegaran. The results showed: at any periodicity Mangkunagara government, emblem Mangkunegaran have such a shape and meaning of different symbols. It is adapted to the characteristics of thinking, government, or philosophical inner Mangkunegaran monarch. Generally elements of the image on the emblem Mangkunegaran contain pictures crown, rice and cotton, sun shine, and logotype MN. As for the difference can be seen from the differences in the form or amount of each type of the picture.
\end{abstract}

Keywords : shape, symbol, emblem, Mangkunegaran 


\section{PENDAHULUAN}

Lambang merupakan bagian identitas yang mewakili sifat, ciri, ataupun visi dan misi dari seorang tokoh maupun organisasi tertentu. Lewat lambang atau logo maka masyarakat percaya pada keagungan atau karakter kuat yang divisualisasikan pada bentuk rupa suatu lambang, karena didalamnya terdapat beberapa simbol yang ditampilkan melalui macam-macam jenis gambar tertentu yang memiliki makna bahkan falsafah tersendiri. Lambang keraton dalam budaya Jawa menjadi daya dukung yang sangat kuat dan merupakan bagian yang tidak terpisahkan dari unsur kebudayaan dan silsilah pemerintahan di dalamnya, seperti keraton Surakarta dan Keraton Mangkunegaran yang memang merupakan dua keraton yang mengemban peran penting sebagai bagian dari pusat kebudayaan Jawa. Keraton Mangkunegaran merupakan generasi penerus perjalanan sejarah kerajaan-kerajaan di Jawa dan menjadi salah satu pusat pelestarian adat yang diwariskan secara turun-temurun. Karena itu, keberadaan Keraton Mangkunegaran dan Keraton Kasunanan, dinilai sangat penting dalam pendinamisasian kehidupan adat dan budaya yang bersumber pada kosmogoni Jawa. Keberadaan dua kerajaan tersebut, menyebabkan masyarakat Jawa mencontoh upacara adat dan budaya yang berkembang di dalam tembok Istana atau Keraton.

Lambang Keraton Mangkunegaran dalam kerangka budaya bukan sekedar simbol kerajaan, melainkan memiliki peran yang lebih luas. Meskipun berwujud simbol, lambang Kerajaan Mangkunegaran tidak hanya digunakan untuk melakukan peran fisik, tetapi ada peran psikis yang bersifat maknawi. Selain itu, lambang ini merupakan salah satu daya tarik kuat pada Kerajaan Mangkunegaran. Salah satu hal yang menarik barangkali karena letaknya yang berada pada setiap sudut istana keraton, seperti pendhapa, gapura, pintu gerbang kerajaan dan setiap sudut kerajaan lainnya dapat kita lihat ketika memasuki Istana Keraton Mangkunegaran. Hal ini unik, karena lambang kerajaan seperti ini hanya terdapat di Keraton Mangkunegaran, tidak dapat kita temui pada kerajaan lain. Tata letak dan tata susun lambang kerajaan ini juga memiliki maksud tersendiri. Ada serangkaian kandungan ajaran di balik wujud lambang yang ingin disampaikan sang penggagas, Kanjeng Mangkunegara. Itulah sebabnya hingga sekarang, wujud simbol kerajaan masih dilestarikan oleh penguasa-penguasa Mangkunegaran berikutnya.

Mengacu pada perspektif budaya, maka bentuk dan corak ungkapan kesenian tidak semata-mata untuk pemenuhan keindahannya saja, melainkan juga terkait secara menyeluruh dengan pemenuhan kebutuhan lainnya. Dengan kata lain, lambang kerajaan dapat dipandang sebagai salah satu cara pemuasan akan keindahan yang keberadaannya ditentukan oleh aspekaspek kebudayaan. Bertolak dari pemikiran itu, maka mengkaji lambang kerajaan sebagai karya seni budaya, pada dasarnya berhadapan dengan tuntutan untuk melihat karya seni itu secara utuh, yang tidak lepas dari keinginan dan ideologi penggagas, yaitu Kanjeng Mangkunegara. Oleh karena itu perlu dipertanyakan bagaimana aspek-aspek kebudayaan eksternal memberikan pengaruh terhadap bentuk ornamen lambang dan maknanya dalam konsep pikir Raja Mangkunegara.

Dari penjelasan tersebut, maka pada penelitian ini, penulis ingin merepresentasikan bentuk rupa dan makna simbolik pada lambang keraton Mangkunegaran dengan menggunakan metode sejarah. Metode sejarah 
digunakan untuk mengungkap latar belakang sejarah dan perkembangan keraton Mangkunegaran, khususnya terkait dengan asal mula makna simbolis dari lambang keraton Mangkunegaran.

Metode sejarah mencakup empat kegiatan, yaitu heuristik atau pengumpulan dan pemilihan sumber yang relevan dengan topik penelitian. Pengumpulan sumber antara lain dilakukan melalui studi arsip, studi pustaka, dan wawancara. Selanjutnya kritik sumber atau menguji secara kritis dengan menyingkirkan bahan-bahan yang tidak otentik dan untuk mendapatkan fakta yang dapat dipercaya. Langkah selanjutnya yaitu interpretasi fakta atau penyimpulan kesaksian dan penafsiran hubungan antarfakta (Gottschalk, 1986: 12). Fakta-fakta yang telah diseleksi selanjutnya diorganisasikan dengan mengikuti alur proses penafsiran hermeunitika yang merupakan kaijan penafsiran terhadap suatu karya, seni, aksi dan tulisan manusia (Palmer, 2005: 45). Penafsiran dilakukan dengan mengumpulkan arsip mengenai penjabaran bentuk rupa dan simbol yang pada lambang keraton Mangkunegaran dan menganalisis makna yang terkandung. Untuk mencapai penafsiran yang lebih baik diperlukan historicalmindedness, sehingga fenomena yang dikaji dapat dilihat sesuai dengan suasana kesejarahan dan kebudayaan pada suatu masa (Kartodirdjo, 1993: 70). Setelah langkah-langkah tadi dilakukan, maka selanjutnya melakukan historiografi atau penyusunan fakta-fakta menjadi tulisan sejarah (1986: 32). Dari penjelasan tersebut tersebut, yang menjadi persoalan atau permasalahan, yakni tentang bagaimana bentuk rupa dan makna simbolik dari lambang keraton Mangkunegaran.

\section{PEMBAHASAN}

\section{Gambaran Umum Keraton Mangkunegaran}

Keraton

Mangkunegaran

Surakarta terletak di Kelurahan Keprabon RT. 20 Kecamatan Banjarsari, Surakarta dengan luas tanah 302,50 x 308,25 m atau 9.345.625 $\mathrm{m}^{2}$. Berbatasan dengan, sebelah selatan adalah jalan Ronggowarsito, bagian barat dengan jalan Kartini, timur dengan jalan Teuku Umar, dan sebelah utara dengan jalan R.M. Said. Bangunan utama Pura Mangkunegaran yaitu Pendapa Ageng yang berbentuk joglo, kemudian Dalem Ageng berbentuk joglo, Dalem Ageng berbentuk limasan, serta Peringgitan yang berbentuk kutuk ngambang (Reksa Pustaka, 2009: 1)

Keraton ini merupakan istana tempat kediaman Sri Paduka Mangkunegara di Surakarta dan dibangun setelah tahun 1757 dengan mengikuti model keraton yang lebih kecil. Secara bentuk bangunan ini memiliki ciri yang sama dengan keraton, yaitu pada pamedan, pendopo, pringgitan, dalem, dan kaputen, yang seluruhnya dikelilingi oleh tembok yang kokoh. Keraton Mangkunegaran menyimpan kesenian dan budaya yang adiluhung, harta dan koleksi yang indah dan tidak ternilai harganya. Seni budaya tersebut sebagian besar berasal dari Majapahit (1293-1478) dan Mataram (1586-1755) masa kekaisaran, tarian topeng klasik, wayang orang (tarian drama), pakaian wayang kulit, dan wayang kayu, patung-patung religius, perhiasan dan benda-benda antik serta pusaka-pusaka yang tidak terhitung nilainya (Wasino, 2014: 16). Hingga saat ini terdapat sembilan periodesasi pemerintahan Mangkunegaran. Berikut ini penjabaran tabel periodesasinya: 
Tabel 1. Periodesasi Pemerintahan Mangkunegaran

\begin{tabular}{|l|r|}
\hline \multicolumn{2}{|c|}{ Periodesasi Pemerintahan Mangkunegaran } \\
\hline Mangkunegara I (Raden Mas Said) & $1757-1796$ \\
\hline Mangkunegara II & $1796-1835$ \\
\hline Mangkunegara III & $1835-1853$ \\
\hline Mangkunegara IV & $1853-1881$ \\
\hline Mangkunegara V & $1881-1896$ \\
\hline Mangkunegara VI & $1896-1916$ \\
\hline Mangkunegara VII & $1916-1944$ \\
\hline Mangkunegara VIII & $1944-1987$ \\
\hline Mangkunegara IX & $1987-$ sekarang \\
\hline
\end{tabular}

\section{Perkembangan Bentuk Rupa Lambang Mangkunegaran}

Pada masa pembangunan hingga diresmikannya bangunan keraton Mangkunegaran pada 1866, yaitu mulai dari masa pemerintahan Mangkunegaran III, lambang keraton Mangunegaran memiliki ketegasan dalam bentuk rupanya. Sebelumnya, saat pemerintahan Mangkunegaran I sampai dengan Mangkunegaran II, lambang dari keraton Mangkunegaran belum terbentuk secara spesifik dan masih dalam bentuk yang sederhana. Visualisasinya hanya terdapat logotype $\mathrm{MN}$ yang menandakan Mangkunegaran dengan disertakan gambar mahkota diatasnya. Namun ketika masa pemerintahan Mangkunegaran III, lambang Mangkunegaran ditambahkan beberapa unsur bentuk rupa yang memiliki makna simbolis.

Dari hasil observasi dan data yang diperoleh, penelitian ini mengkaji beberapa lambang keraton Mangkunegaran yang mengalami perubahan, yaitu pada masa pemerintahan Mangkunegaran III, Mangkunegaran IV, Mangkunegaran VIII dan Mangkunegaran IX. Pada pembahasan dibawah ini, berisi tinjauan mengenai bentuk rupa dan makna distian jenis gambar yang ada di dalam lambang Mangkunegaran, kemudian di pembahasan terakhir dijelaskan apa saja yang menjadi unsur pembeda pada setiap perubahan yang ada di lambang Mangkunegaran.

\section{Jenis-Jenis Gambar dan makna simbolis pada Lambang Keraton Mangkunegaran}

Dilihat dari perkembangan munculnya lambang keraton Mangkunegaran yang disesuaikan dengan periode pemerintahan masingmasing raja Mangkunegaran, ada beberapa gambar yang selalu ditampilkan pada lambang keraton Mangkunegaran. Gambar tersebut menampilkan beberapa jenis, diantaranya yaitu gambar mahkota, gambar logotype M. N., gambar padi dan kapas, dan gambar surya.

\section{Gambar Mahkota}

Tradisi penggunaan gambar mahkota sudah ada sejak masuknya agama islam dan memunculkan kerajaankerajaan pecahan baru yang berlandaskan agama islam seperti kerjaan Samudra Pasai, Demak, dan kerajaan Mataram. Penggunaan gambar mahkota pada 
lambang keraton juga masih berlangsung hingga munculnya kolonialisme Belanda yang memisahkan daerah pemerintahan kerajaan Mataram menjadi daerah vorstenlanden, yaitu didirikannya keraton/istana didaerah itu. Keraton tersebut, diantaranya adalah keraton Ngayogyakarta, keraton Surakarta Hadiningrat, dan keraton Mangkunegaran Surakarta.

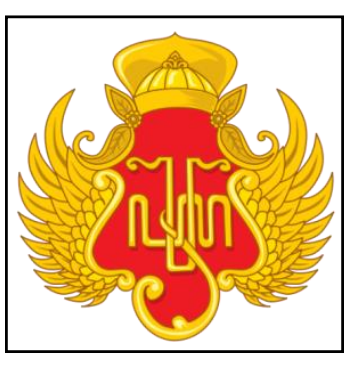

A

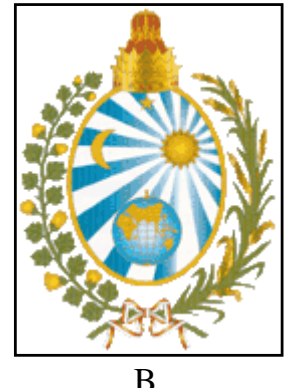

B
Gambar 1.

A. Lambang keraton Ngayogyakarta,

B. Lambang keraton Surakarta Hadiningrat.

Sumber: (Online) https://www.google.co.id, diunduh pada 27 Januari 2017.

Penggunaan gambar mahkota pada lambang keraton Mangkunegaran ada bermacam-macam bentuknya. Hal tersebut ditambah dengan adanya akulturasi antara kebudayaan Eropa (dibawa oleh kolonialisme Belanda) dan kebudayaan Jawa. Kebudayaan Eropa yang terlihat pada gambar mahkota yaitu dengan adanya gambar mahkota di salah satu lambang keraton yang menyerupai mahkota kerajaan Belanda. Sedangkan pada kebudayaan Jawa, gambar mahkota diadopsi dari bentuk mahkota yang dipakai oleh salah satu tokoh dalam pewayangan Jawa yang bernama Basukarna atau Adipati Karna (tokoh lima pandawa dalam cerita Mahabarata).
Tokoh Basukarna sesuai dengan penggambaran posisi Raden Mas Said yang keduanya sama-sama tidak mendapat gelar pangeran dan tidak mempunyai kesempatan menduduki jabatan di kerajaan. Sadar akan posisinya, maka Basukarna akhirnya membuat kerajaan di wilayah yang baru bersama keempat saudaranya, yaitu Arjuna, Bima, Nakula dan Sadewa. Begitu pula dengan Raden Mas Said yang pada akhirnya meminta tanah lungguh/Apanase dan mendirikan kerajaan sendiri, yaitu istana Mangkunegaran.

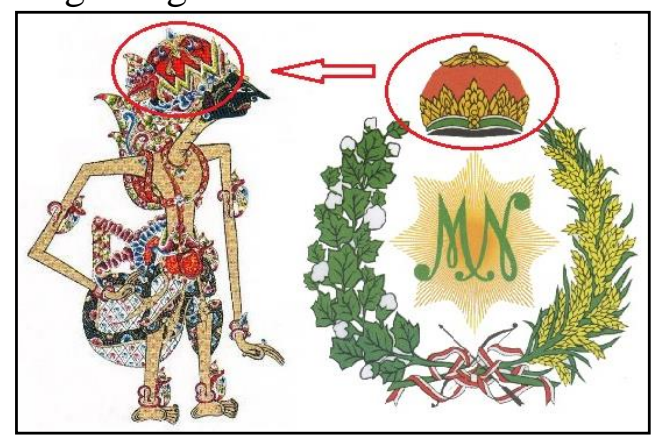

Gambar 2. Visualisasi bentuk mahkota pada tokoh Basukarna yang mirip dengan gambar mahkota pada lambang keraton Mangkunegaran. Sumber:(https://safaribudiharjo.wordpress.com/, diunduh pada 27 Januari 2017 ,

Gambar Logotype "MN"

Logotype juga bisa digolongkan sebagai seni tipografi. Gambar Logotype $\mathrm{MN}$, merupakan singkatan dari Mangku Negaran. Gambar ini juga selalu ada di setiap lambang Mangkunegaran, hanya saja yang membedakan adalah bentuk variasi hurufnya saja. lebih jelasnya dapat dilihat dari beberapa potongan Logotype MN dalam bentuk rupa lambang Mangkunegaran di bawah ini.

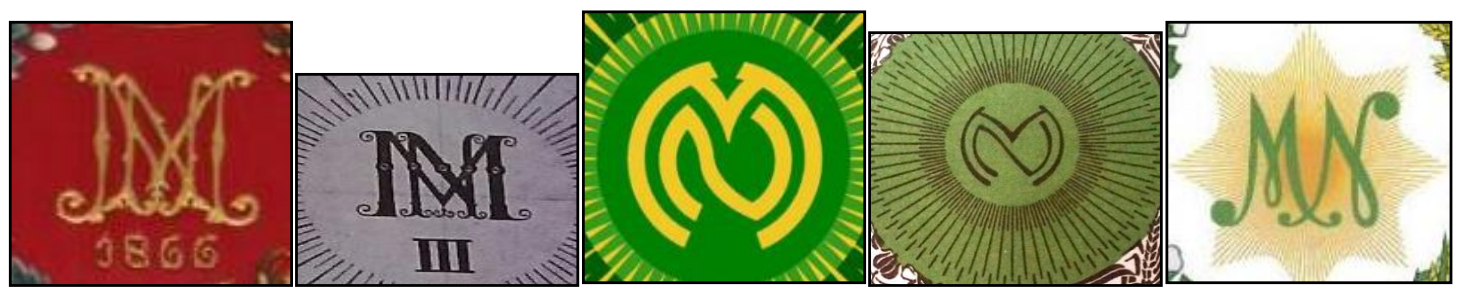

Gambar 3. Potongan macam-macam Logotype M. N pada Lambang Mangkunegaran. Sumber: Dokumentasi Peneliti. 
Gambar Padi dan Kapas

Gambar padi dan kapas sering ditemukan pada lambang-lambang organisasi, instansi, negara, kota/daerah, lembaga formal, maupun istana atau keraton. Padi melambangkan kemakmuran. Seperti yang kita ketahui bahwa padi merupakan makanan pokok masyarakat Indonesia. Hal tersebut berarti bahwa terpenuhinya keperluan masyarakat yang berkaitan dengan bahan dan kebutuhan pokok sehari-hari, khususnya dalam hal pangan. Sehingga gambar padi diartikan sebagai simbol pemenuhan segala kebutuhan pokok (Yurica Oentoro, 2012: 9).

Kapas diartikan sebagai lambang kesejahteraan. Hal ini mengandung makna bahwa segala kebutuhan masyarakat yang terkait dengan sandang dan papan akan dapat tercukupi. Seperti yang kita ketahui bahwa kapas dapat diartikan sebagai bahan baku pembuat kain dan pakaian, sehingga penekanan lambang ini adalah kebutuhan sekunder yang berkaitan dengan sandang dan papan/tempat tinggal (2012: 10).

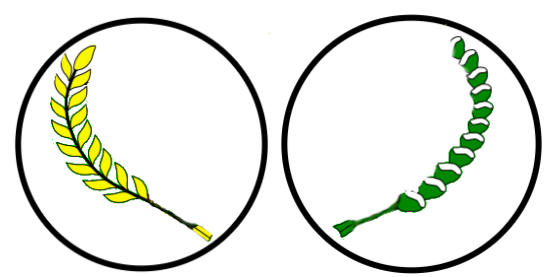

Gambar 4. Visualisasi Bentuk Gambar Padi dan Kapas yang Biasa ada pada Lambang

Sumber: Online

(http://www.bin.go.id/wawasan/detil/167/3/26/11 /2012/filosofi-garuda-pancasila)

Apabila digabungkan, lambang padi dan kapas adalah suatu simbol citacita bahwa keperluan masyarakat yang terkait dengan bahan makanan yaitu pangan dan bahan sekunder lainnyaseperti pakaian dan tempat tinggal dapat dipenuhi sehingga menjadikan kehidupan masyarakatnya adil, makmur dan sejahtera secara merata. Hal ini juga telah tertanam pada landasan negara kita, yaitu pancasila sila ke lima yang berbunyi keadilan sosial bagi seluruh rakyat Indonesia. Sila ini dilambangkan dengan ikon padi dan kapas.

Gambar padi dan kapas pada lambang negara Indonesia menandakan sandang dan pangan, merupakan bahan kemakmuran lahiriah sebagai sarana kemakmuran batiniah, padi dan kapas melambangkan keadilan dan kemakmuran seluruh rakyat Indonesia yang menjadi tujuan Bangsa dan Negara RI (Hidayat, 2007). Di dalam Penjelasan atas Peraturan Pemerintah no. 66 Tahun 1951 tentang lambang negara pasal 4 dijelaskan tentang ikon dari sila terakhir ini. Warna yang terdapat pada ikon terakir Pancasila ini adalah warna putih, hijau dan kuning. Warna-warna ini merupakan indeks yang terdapat pada gambar padi dan kapas ini. Warna hijau pada gambar ini memberikan indikasi tentang kesuburan, kesegaran dan kehidupan. Warna putih memberikan indikasi tentang kedamaian dan kesempurnaan. Yang terakhir adalah warna kuning yang memberikan indikasi tentang warna dari padi yang matang.

\section{Gambar Surya}

Gambar surya atau biasa diberi julukan madangi (menerangi) maupun Suryasumunar memiliki arti matahari. Diketahui bahwa, gambar surya yang dijadikan ornamen pada sebuah lambang mulanya berasal dari kerajaan Majapahit. Meski sebelum abad ke-10 sudah berdiri sejumlah kerajaan besar di nusantara, lambang dari Kerajaan Majapahit (12931500) adalah identitas tertua dari kerajaan Nusantara yang masih dapat diidentifikasi. Sebuah ornamen yang dikenal dengan nama Surya Majapahit, sementara banyak dianggap sebagai lambang kerajaan yang pernah mencapai kejayaannya di seluruh penjuru Nusantara itu. Surya Mapapahit adalah ornamen yang umumnya ditemui di situs- 
situs peninggalan Majapahit. Ornamen ini dapat ditemukan di langit-langit garbhagriha, salah satu ruangan tersuci di Candi Penataran. Ornamen ini juga ditemukan di Candi Bangkal
(Mojokerto), Candi Sawentar (Blitar) dan di batu-batu nisan yang berasal dari zaman Majapahit di seputar wilayah Trowulan (Mojokerto).

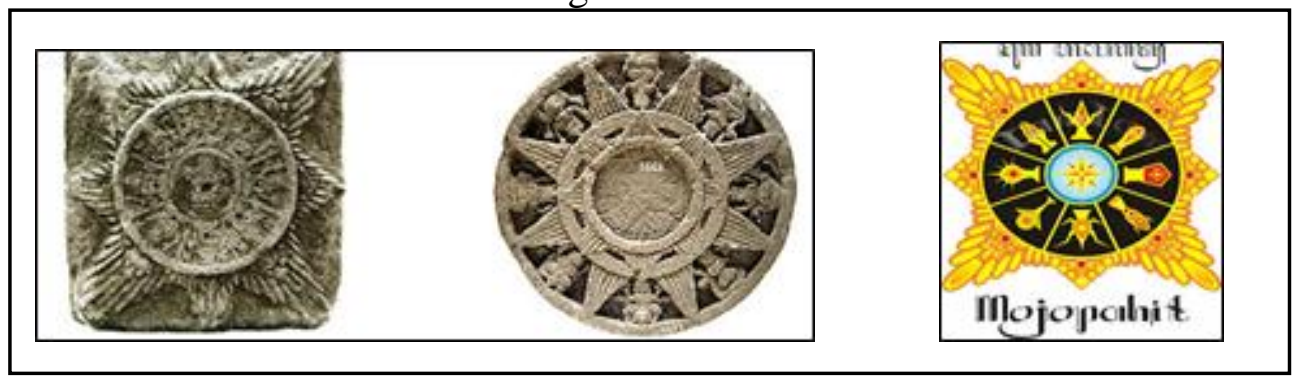

Gambar 5. Beberapa bentuk rupa lambang kerajaan Majapahit.

Dari visualisasi lambang Majapahit inilah keraton Mangkunegaran yang apabila dilihat dari sisi sejarahnya, Mataram Islam masih memiliki hubungan dengan kerajaan Majapahit. Melestarikan tradisi budayanya dengan menampilkan gambar surya pada lambang keratonnya. Penerapan gambar surya pada lambang keraton Mangkunegaran mulai ada sejak pemerintahan Mangkunegaran III. Jika pada kerajaan Majapahit jumlah surya merupakan perwujudan dewa-dewa agama Hindu, lain hal nya dengan lambang keraton Mangkunegaran yang meletakan jumlah surya berdasarkan jumlah silsilah atau anggota keluarga maupun abdi dalem pada pemerinahan Mangkunegaran tersebut. Tentunya, dalam setiap pergantian periode pemerintahan antara Mangkunegaran satu dengan yang lainnya bisa memiliki jumlah atau bentuk yang berbeda, tergantung pada falsafah, ketetapan, dan prinsip hidup dari raja Mangkunegara yang sedang menjabat.

\section{Perbedaan Makna pada Lambang Keraton Mangkunegaran}

Seperti yang sudah dijabarkan pada subbab terdahulu, bahwa setiap periodesasi pemerintahan Raja Mangkunegara, memiliki lambang Mangkunegaran yang berbeda. Hal tersebut khususnya penulis temui pada bentuk rupa lambang Mangkunegara III, IV, VIII, dan IX. Faktor pembeda lambang tersebut bukan berarti antara lambang satu dengan yang lain tidak mempunyai unsur kemiripan, melainkkan sebaliknya. Pada setiap lambang Mangkunegaran, secara filosofis dan jenis gambar simbolisnya sama, hanya saja yang membedakan adalah ciri/bentuknya, jumlahnya, ataupun warnanya. Sejarah munculnya lambang keraton Mangkunegaran, menurut hasil wawancara peneliti dengan salah seorang abdi dalem keraton, bahwa lambang Mangkunegaran sudah ada sejak masa praja Mangkunegara I, namun bentuk rupa lambang tersebut masih belum tegas, atau masih berbeda-beda. Lambang keraton yang tetap mulai ada sejak bangunan Pure Mangkunegaraan diresmikan, yaitu pada tahun 1866 atau pada masa Mangkunegara IV. Hal ini dibuktikan dengan dicantumkannya tahun peresmian tersebut pada lambang Mangkunegaran yang diletakan di pendhopo agung atau bisa digambarkan sebagai aula utama keraton Mangkunegaran. Namun demikian, untuk lambang Mangunegaran masa itu belum mendapatkan lambang yang konsisten sama. Kemudian, barulah pada masa pemerintahan Mangkunegaran III mulai ditegaskan bentuk awal dari lambang Mangkunegaran. Hal ini didasari karena 
saat itu sudah dimulai babak orde baru, yang menuntut segala instansi pemerintahan mempersiapkan dengan rinci dan baik terkait kelengakapan unsur pemerintahannya. Setelah habis masa pemerintahan Mangkunegara III, lambang Mangkunegaran tidak mengalami perubahan yang signifikan. Baru ketika masa pemerintahan Mangkunegaran VIII lambang Mangkunegaran mengalami perubahanperubahan yang akan lebih rinci dibahas berikut ini.

Lambang Mangkunegaran III

$$
\text { Masa periode praja }
$$

Mangkunegara III mempunyai sebutan "Suryosumunar". Praja ini bisa dikatakan yang paling memiliki banyak peninggalan arsip. Hal ini karena istri dari presiden Soeharto merupakan keturunan dari KGPAA Mangkunegaran III. Maka

pada masa Orde Baru, praja Mangkunegaran mengalami kejayaan, terutama dalam hal budaya. Setiap tahun rutin diadakan rangkaian upacara Kholagung Mangkunegaran III Suryosumunar. Acara-acara budaya ini menjadikan terbitnya banyak dokumen kerajaan periode Mangkunegaran III. Seperti data yang telah diperoleh peneliti terkait rincian makna simbol lambang Mangkunegaran, sebagai berikut.

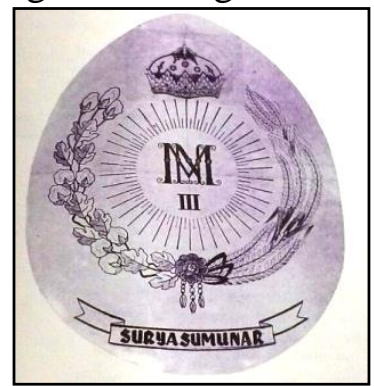

Gambar 6. Lambang praja Mangkunegaran III. Sumber: Arsip perpustakaan Rekso Pustoko Mangkunegaran.

2) Butiran-butiran Merah, 5 butir, artinya Panca mutiara wasiat Mangkunegaran III.

4) Surya, artinya madhangi (menerangi) atau suryosumunar. Anom" lambang, tunggul ("bendera") Mangkunegaran.

5) Bentuk Perisai (schild), artinya menolak bahaya, mengayomi (melindungi).

7) Mahkota (Makutha Kadipatenwayang), artinya lambang Mangkunegaran.

6) Jumlah sinar, ada 42 panjang pendek berarti 42 keturunan putraputri Mangkunegaran III.

8) Padi dan kapas, menandakan sandhang pangan, dan lambang kemakmuran.

9) "MN", merupakan singkatan dari Mangku Negaran.

10) Kapas 3 tangkai bunga, masingmasing berdaun 3 , padi 3 ikat masing-masing 3 tangkai. Jumlahnya melambangkan trah Mangunegaran yang ke III.

11) Berbentuk tegak, menandakan trah MN selalu tegak, tabah menghadapi segala tugas dan segala kesukaran dengan penuh rasa percaya diri ("mulat sarira hangrasa wani").

Ketiganya menjadi satu lambang kembang telon: trah Mangkunegaran III berkembang mewangi. kembang telon
12) Bunga mawar jambu artinya harum namanya, kusuma bangsa. Bunga melati, artinya suci, jujur atau bersih. Bunga kanthil, artinya saling membutuhkan.

merupakan simbol harmoni antara warna langit, manusia, dan bumi (Sumardjo, 2007 : 123). Suryasumunar, Surya yaitu 
matahari, diambilkan dari bangian pertama nama-nama putra dalem Mangkunegaran III, yaitu Suryadiningrat, Suryamataram, Suryaputra, dan Suryahudaya. Sedangkan Sunar artinya sinar, sorot atau cahaya. Suryasumunar berarti matahari bersinar. Hal tersebut mengibaratkan kerukunan yang menimbulkan "terang" batinah, terhindar dari percekcokan yang merupakan kegelapan. Warna huruf hitam berarti langgeng, abadi, maka artinya yaitu "kerukunan yang langgeng".

Lambang Mangkunegaran IV

Raden Mas Sudira merupakan nama kecil dari KGPAA Mangkunegara IV. Saat pemerintahannya pembangunan istana telah selesai dan diresmikan. Di atap ruang pendhapa ageng terdapat lambang Mangkunegaran IV berupa ukiran kayu menyatu dengan plafon.

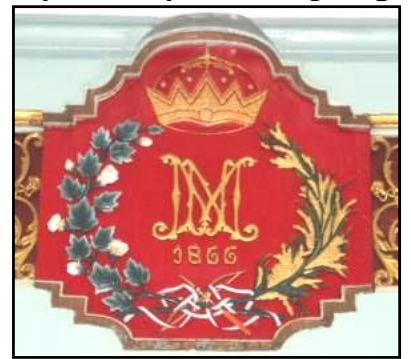

Gambar 7. Lambang praja Mangkunegaran IV berupa ukiran kayu pada atap pendhapa ageng keraton Mangkunegaran. Sumber: Dokumentasi peneliti.

Lambang Mangkunegaran VIII

$$
\text { KGPAA Mangkunegara }
$$

VIII (lahir di Kartasura, 7 April 1925 - meninggal di Surakarta, 2 Agustus 1987 pada umur 62 tahun, mulai berkuasa 1944) adalah penguasa Praja Mangkunegaran terakhir yang mengalami masa kolonial Belanda dan yang pertama kali saat Indonesia merdeka. Baru saja dilantik dan kemudian harus menghadapi arus perubahan politik yang besar, Mangkunegara VIII (bersama Pakubuwana XII) kesulitan memposisikan diri untuk menjaga kedaulatan wilayah. Akibatnya Daerah Istimewa
Surakarta digabungkan ke dalam Provinsi Jawa Tengah sejak 1950. Mangkunegara VIII menjalankan roda monarki Mangkunegaran dengan berbagai upaya dan usaha. Pada tahun $\underline{1970}$ oleh Mangkunegara VIII digali kembali dan dihidupkan. Selain menggali kembali Tari Bedaya Anglir Mendung, ia juga menciptakan sebuah tarian kerakyatan yang disebut Tari Gambyong Retno Kusumo. ketertarikan beliau dalam bidang seni juga terlihat pada lambang praja Mangkungaran IV. Dilihat dari bentuk rupanya lambang paling berbeda dengan lambang Mangkunegaran lainnya.

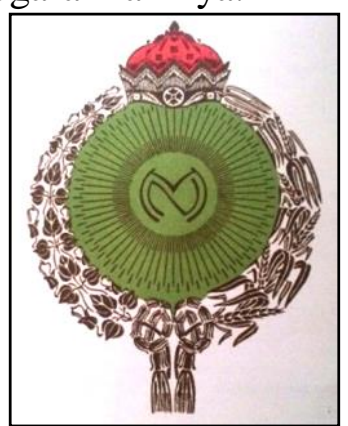

Gambar 8. Lambang praja Mangkunegaran VIII Sumber: Arsip perpustakaan Rekso Pustoko Mangkunegaran.

Lambang Mangkunegaran IX

KGPAA Mangkunegaran

IX merupakan Mangkunegara yang masih menjabat sampai saat ini. Lambang Mangkunegaran IX mirip dengan lambang Mangkunegaran IV. Perbedaannya ada pada warna dan gambar surya. Lambang Mangkunegaran IX terdapat gambar surya, tetapi Mangkunegaran IV tidak ada.

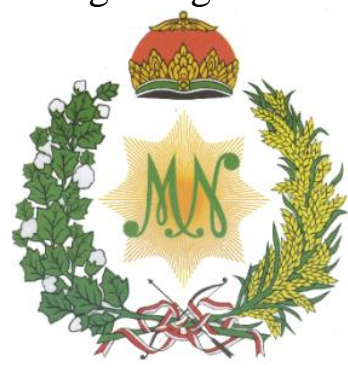

Gambar 9. Lambang praja Mangkunegaran IX. 
Wujud lambang praja Mangkunegaran IX hingga saat ini banyak dijumpai dibeberapa sudut keraton. Diantaranya pada ruangan Dalem Pringgitan, yaitu bangunan yang dipergunakan untuk menerima tamu resmi dan tempat pementasan wayang,serta ruangan Dalem Ageng, bangunan yang biasanya berbentuk senthong, dengan bentu limasan tanpa plafon. Di dalamnya disimpan koleksi benda-benda bersejarah dan benda-benda untuk upacara tradisional.
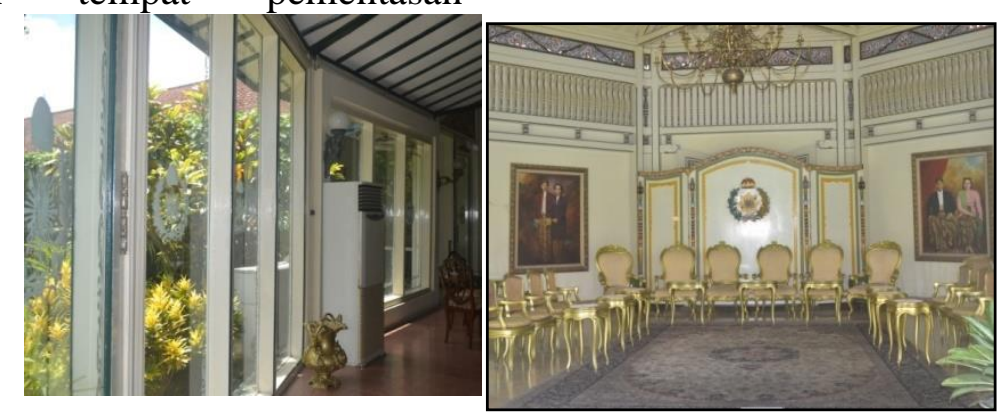

Gambar 10. Peletakan lambang praja Mangkunegaran IX diruang Dalem Pringgitan dan di kaca jendela bangunan Dalem Ageng.

Sumber: Dokumentasi peneliti.

Tabel 2. Perbedaan keempat lambang praja Mangkunegaran

\begin{tabular}{|c|c|c|c|c|c|}
\hline Lambang & Mahkota & Padi dan Kapas & $\begin{array}{c}\text { Logotype } \\
\text { MN }\end{array}$ & Surya & $\begin{array}{c}\text { Pita/Simpul } \\
\text { Tali }\end{array}$ \\
\hline $\begin{array}{l}\text { Mangkunegara } \\
\text { III }\end{array}$ & $\begin{array}{l}\text { Bentuk } \\
\text { seperti } \\
\text { mahkota tokoh } \\
\text { pewayangan } \\
\text { Basukarna }\end{array}$ & $\begin{array}{l}\text { Padi dan kapas } \\
\text { berada } \\
\text { melingkari } \\
\text { bentuk lambang. } \\
\text { Jumlah bunga } \\
\text { kapas dan } \\
\text { gerombolan } \\
\text { padi. Satu } \\
\text { rangkai bunga } \\
\text { kapas terdiri dari } \\
3 \text { bunga dan } \\
\text { begitupula } \\
\text { dengan } \\
\text { rangkaian padi } \\
\text { yang jumlahnya } \\
3 \\
\text { ikat,menandakan } \\
\text { periodesasi praja } \\
\text { mangkunegara } \\
\text { III. }\end{array}$ & 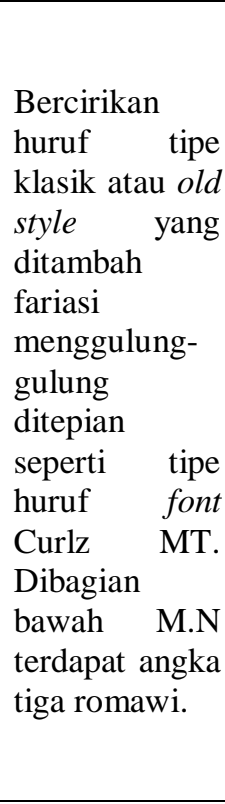 & $\begin{array}{l}\text { Jumlah } \\
\text { sinarnya } \\
\text { melambangkan } \\
42 \text { keturunan } \\
\text { dari } \\
\text { Mangkunegara } \\
\text { III. Tampilan } \\
\text { gambarnya } \\
\text { melingkar dan } \\
\text { terdiri dari } \\
\text { garis-garis } \\
\text { panjang } \\
\text { pendek. }\end{array}$ & $\begin{array}{l}\text { Bentuk pita } \\
\text { disimbolkan } \\
\text { dengan gambar } \\
\text { kembang telon. }\end{array}$ \\
\hline $\begin{array}{l}\text { Mangkunegara } \\
\text { IV }\end{array}$ & $\begin{array}{l}\text { Bentuk seperti } \\
\text { mahkota tokoh } \\
\text { pewayangan } \\
\text { Basukarna }\end{array}$ & $\begin{array}{l}\text { Padi dan kapas } \\
\text { berada } \\
\text { melingkari } \\
\text { bentuk lambang. } \\
\text { Untuk jumlah } \\
\text { bunga kapas dan } \\
\text { rangkaian padi } \\
\text { tidak ditentukan } \\
\text { berdasarkan } \\
\text { periodesasi }\end{array}$ & $\begin{array}{l}\text { Logotype M. N } \\
\text { mercirikan } \\
\text { huruf tipe } \\
\text { klasik atau old } \\
\text { style yang } \\
\text { ditambah } \\
\text { variasi } \\
\text { menggulung- } \\
\text { gulung } \\
\text { ditepian } \\
\text { seperti tipe }\end{array}$ & $\begin{array}{l}\text { Tidak terdapat } \\
\text { gambar sinar }\end{array}$ & $\begin{array}{lr}\text { Terdapat pita } \\
\text { merah putih } \\
\text { Pita namun } \\
\text { bukan lambang } \\
\text { nasional } \\
\text { Republik } \\
\text { Indonesia, } \\
\text { melainkan } \\
\text { simbol gulo } \\
\text { klopo yang } \\
\text { berkaitan }\end{array}$ \\
\hline
\end{tabular}




\begin{tabular}{|c|c|c|c|c|c|}
\hline & & $\begin{array}{l}\text { Mangkunegara } \\
\text { IV. }\end{array}$ & $\begin{array}{ll}\text { huruf } & \text { Curlz } \\
\text { MT. } & \end{array}$ & & $\begin{array}{l}\text { dengan ritus } \\
\text { kesuburan } \\
\text { dalam religi } \\
\text { Jawa Kuno. }\end{array}$ \\
\hline $\begin{array}{l}\text { Mangkunegara } \\
\text { VIII }\end{array}$ & $\begin{array}{l}\text { Bentuk seperti } \\
\text { mahkota tokoh } \\
\text { pewayangan } \\
\text { Basukarna }\end{array}$ & $\begin{array}{l}\text { Padi dan kapas } \\
\text { yang berwarna } \\
\text { coklat berada } \\
\text { melingkari } \\
\text { bentuk lambang. } \\
\text { Untuk jumlah } \\
\text { bunga kapas dan } \\
\text { rangkaian padi } \\
\text { tidak ditentukan } \\
\text { berdasarkan } \\
\text { periodesasi } \\
\text { Mangkunegara } \\
\text { VIII }\end{array}$ & $\begin{array}{l}\text { Logotype M. } N \\
\text { mercirikan } \\
\text { huruf seni } \\
\text { typografi yang } \\
\text { masuk } \\
\text { kedalam jenis } \\
\text { huruf display } \\
\text { dekoratif } \\
\text { berbentuk } \\
\text { cembung. }\end{array}$ & $\begin{array}{l}\text { Tampilan } \\
\text { gambar surya } \\
\text { melingkar dan } \\
\text { terdiri dari } \\
\text { garis-garis } \\
\text { panjang } \\
\text { pendek. }\end{array}$ & \\
\hline $\begin{array}{l}\text { Mangkunegara } \\
\text { IX }\end{array}$ & $\begin{array}{l}\text { Bentuk seperti } \\
\text { mahkota tokoh } \\
\text { pewayangan } \\
\text { Basukarna }\end{array}$ & $\begin{array}{l}\text { Padi dan kapas } \\
\text { berada } \\
\text { melingkari } \\
\text { bentuk lambang. } \\
\text { Jumlah bunga } \\
\text { kapas dan } \\
\text { gerombolan } \\
\text { padi. Rangkaian } \\
\text { ibunga kapas } \\
\text { terdiri dari } 9 \\
\text { bunga dan } \\
\text { begitupula } \\
\text { dengan } \\
\text { rangkaian padi } \\
\text { yang jumlahnya } \\
9 \\
\text { ikat,menandakan } \\
\text { periodesasi praja } \\
\text { mangkunegara } \\
\text { IX. }\end{array}$ & $\begin{array}{l}\text { Logotype M. N } \\
\text { mercirikan } \\
\text { huruf old style } \\
\text { huruf seni } \\
\text { typografi yang } \\
\text { masuk } \\
\text { kedalam jenis } \\
\text { huruf display } \\
\text { dekoratif } \\
\text { berbentuk } \\
\text { cembung. }\end{array}$ & $\begin{array}{l}\text { Tampilan } \\
\text { gambarnya } \\
\text { melingkar dan } \\
\text { terdiri dari } \\
\text { garis-garis } \\
\text { panjang } \\
\text { pendek. }\end{array}$ & $\begin{array}{l}\text { Terdapat pita } \\
\text { merah putih } \\
\text { seperti lambang } \\
\text { bendera } \\
\text { nasional } \\
\text { Republik } \\
\text { Indonesia. } \\
\text { Mengisyaratkan } \\
\text { bahwa Praja } \\
\text { Mangkunegara } \\
\text { berada di bawah } \\
\text { kedaulatan } \\
\text { Negara } \\
\text { Kesatuan } \\
\text { Republik } \\
\text { Indonesia }\end{array}$ \\
\hline
\end{tabular}

\section{PENUTUP}

\section{Lambang}

Keraton

Mangkunegaran dalam kerangka budaya bukan hanya simbol yang biasa digunakan sebagai tanda kerajaan, melainkan memiliki peran yang lebih luas sebagai salah satu falsafah Jawa. Keraton Mangkunegaran yang berdiri pada tahun 1757 dengan pendirinya Raden Mas Said mengalami perkembangan struktur pemerintahan maupun corak kebudayaan. Hal ini juga mempengaruhi bentuk rupa lambang Mangkunegara.

Pada penelitian yang telah dilakukan terdapat beberapa perubahan lambang Mangkunegara. Perubahan lambang Mangkunegara dapat dilihat pada periodesasi Mangkunegara III, Mangkunegara IV, Mangkunegara VIII, Mangkunegara IX. Secara umum komposisi lambang Mangkunegara adalah rangkaian dari beberapa gambar mahkota, padi dan kapas, surya, logotype MN, dan pita/ simpul tali. Gambarl mahkota mempunyai kemiripan dengan tokoh pewayangan Basukarna, Padi dan kapas sebagai simbol sandang dan pangan juga ada yang melambangkan periodesasi Mangkunegara, logotype $\mathrm{MN}$ yaitu akronim dari Mangku dan Negara, Surya sebagai matahari yang diadopsi 
dari lambang Surya Majapahit, dan pita/ simbol tali yaitu ritus kesuburan dan isyarat bahwa Keraton Mangkunegara berada di bawah kedaulatan Negara Republik Indonesia. Dari semua hasil penelitian yang telah didapat, Lambang Mangkunegara III merupakan yang paling banyak sumber data dikarenakan pada masa Orde Baru, banyak dilakukan acara adat untuk mengenang Mangkunegara III. Keterbatasan sumber data tulis lambang Mangkunegara dikarenakan adanya anggapan sakral bagi para abdi dalem terhadap lambang yang didesain oleh Kanjeng Mangkunegara pada masanya.

\section{DAFTAR PUSTAKA}

Abdullah, T. (1985) "Pendahuluan: Sejarah dan Historiografi", dalam Taufik Abdullah dan Abdurrachman Surjomihardjo, editor, Ilmu Sejarah dan Historiografi: Arah dan Perspektif. Jakarta: Gramedia.

Berryman, G. (1979). Notes on Graphic Design and Visual Communication. Los Altos. William Kaufmann, Inc.

Dejalantik, A. A. M. (2008). Estetika: Sebuah Pengantar (Jakarta: Masyarakat Seni Pertunjukan Indonesia (MSPI)).

Gottschalk, L. (1986). Mengerti Sejarah, diindonesiakan oleh Nugroho Notosusanto. Jakarta: Penerbit Universitas Indonesia

Hidayat, N. R. (2009). Mencari Telur Garuda. Jakarta: Nalar.
Kartodirdjo, S. (1993). Pendekatan Ilmu Sosial dalam Metodologi Sejarah. Jakarta: Gramedia Pustaka Utama.

Kusrianto, A. (2007). Pengantar Desain Komunikasi Visual. Yogyakarta: CV. Andi Offset.

Panitia Penyusun Kerabat Mangkunegaran, (1949). Mangkunegaran Selayang Pandang, Surakarta : Mangkunegaran.

Palmer, R. E. (2005). Hermeneutika Teori Baru Mengenai Interpretasi, diindonesiakan oleh Musnur Hery \& Damanhuri Muhammad. Yogyakarta: Pustaka Pelajar.

Sumardjo, J. (2007). Jeihan: Ambang Waras dan Gila. Bandung: Jeihan Institute

Tinarbuko, S. (2009). Semiotika Komunikasi Visual. Yogyakarta: Jalasutra.

Wasino. (2014). Modernisasi di jantung budaya Jawa: Mangkunegaran, 1896-1944. Jakarta: Penerbit Buku Kompas.

Jurnal:

Oentoro, Y. (2012), Representasi Figur Burung Garuda yang Digunakan sebagai Lambang Negara. Program Studi Desain Komunikasi Visual, Fakultas Seni dan Desain, Universitas Kristen Petra 